\title{
Regulation of hepatic lipogenesis by dietary maize oil or tripalmitin in the meal-fed mouse
}

\author{
BY G. R. HERZBERG AND N. JANMOHAMED \\ Department of Biochemistry Memorial University of Newfoundland, \\ St. John's, Newfoundland $A$ I $B{ }_{3} X_{9}$ Canada
}

(Received 8 October I979-Accepted 30 November 1979)

1. The effect of varying dietary levels of maize oil and tripalmitin $(0-250 \mathrm{~g} \mathrm{fat} / \mathrm{kg}$ ) on hepatic lipogenesis and the levels of hepatic fatty acid synthetase (FAS), glucose-6-phosphate dehydrogenase (EC I I I I .49; G6PD), malic enzyme (EC I. I.I.38, I. I.I.39, I. I.I.40; ME) and glucokinase (EC 2.7.1.2; GK) was examined in meal-fed mice.

2. Meal-fed mice compared to mice fed ad lib. show enhanced hepatic lipogenesis as demonstrated by an increased rate of in vivo fatty acid synthesis and increased levels of FAS, ME and G6PD. The level of GK in meal-fed mice was unchanged by meal feeding.

3. Maize oil more effectively reduced in vivo hepatic lipogenesis than tripalmitin in meal-fed mice.

4. Maize oil more effectively reduced the hepatic levels of FAS, G6PD, ME and GK than tripalmitin in meal-fed mice.

5. The increased inhibition by maize oil is observed at all levels of fat in the diet investigated and has been shown not to be due to decreased carbohydrate intake nor to differences between the absorption of maize oil and tripalmitin.

The rate of fatty acid synthesis and the activity of the lipogenic enzymes in mouse and rat liver are regulated by both the level and type of dietary fat (Hill et al. 1958; Allman \& Gibson, 1965; Jansen et al. 1966; Sabine et al. 1969; Wiegand et al. 1973; Musch et al. 1974; Waterman et al. 1975; Clarke et al. 1976, 1977a, b, c; Triscari et al. 1978). However, reports on the effect of saturated $v$. unsaturated lipids on the synthesis of fatty acids have been conflicting. Lipogenesis measured in vitro was shown to be inhibited equivalently by maize oil or hydrogenated vegetable oil and lard (Hill et al. 1958). Yeh et al. (1970) demonstrated that hepatic lipogenesis measured in vitro was lower in rats given safflower oil compared to those given tallow although no differences were observed by these workers in the chick. This is in contrast to the finding of Dupont (1970) who showed that the rate of hepatic lipogenesis as determined in vitro was the same whether rats were given safflower oil or tallow. In still another study using both rats and mice safflower oil inhibited hepatic fatty acid synthesis while tripalmitin and triolein were without effect (Bartley \& Abraham, 1972). Several studies with mice and rats using methyl or ethyl esters of palmitate or linoleate have found that hepatic lipogenesis is inhibited by the ester of linoleate but unaffected by palmitate (Allman \& Gibson, 1965; Clarke et al. 1976, 1977a, $b, c$; Triscari et al. 1978).

The majority of studies concerning the effect of type or amount of fat on hepatic lipogenesis have only investigated one of these variables. Recently, Triscari et al. (I 978) reported on the effects of varying levels of maize oil or hydrogenated soya-bean oil on lipogenesis in vivo in meal-fed rats. They concluded that maize oil was an effective inhibitor at all levels above $10 \mathrm{~g} / \mathrm{kg}$ while hydrogenated soya-bean oil was without effect. Whether or not hepatic lipogenic enzymes respond in a similar manner was not determined.

The present study was undertaken to define the effects of saturated $v$. unsaturated dietary fat on lipogenesis in mouse liver. Mice were meal-fed diets containing 0, 50, 100, I 50, 200, $250 \mathrm{~g}$ maize oil or tripalmitin $/ \mathrm{kg}$ for $7 \mathrm{~d}$. Hepatic lipogenesis was assessed in vivo and the activities of fatty acid synthetase (FAS), glucose-6-phosphate dehydrogenase (EC I . I . I . 49; 
G6PD), malic enzyme (EC I.I.1.40; ME) and glucokinase (EC 2.7.I.2; GK) were determined in vitro.

\section{METHODS}

Male $\left(\mathrm{C}_{57} \mathrm{BL} / 6 \mathrm{~J}\right)$ mice, 8-10 weeks of age obtained from Jackson Lab, Bar Harbour, Maine, USA were used throughout the study. The animals were maintained in a lightcontrolled (lights on 09.00-2 1.00 hours) room at a temperature of approximately $23^{\circ}$. The mice were trained to consume their entire daily food ration in a $3 \mathrm{~h}$ period from $09.00-$ I 2.00 hours. The training period lasted $7 \mathrm{~d}$ at which time the animals began consuming the experimental diets. The experimental diets had the composition indicated in Table $\mathrm{I}$. The fatty acid composition of the diets is shown in Table 2. Six diets were used for each type of fat examined containing $0,50,100,150,200$, and $250 \mathrm{~g}$ fat $/ \mathrm{kg}$. The animals were maintained in metabolic cages and weighed at the beginning of the experimental diet period and after $8 \mathrm{~d}$.

At the conclusion of the eighth meal of the experimental diet, the animals were injected intraperitonially with $100 \mu \mathrm{Ci}^{3} \mathrm{H}_{2} \mathrm{O}$ and 60 min later decapitated. A sample of blood was taken for determination of plasma specific activity. The liver was rapidly removed and approximately half was homogenized in cold $0.15 \mathrm{M}$-potassium chloride, $\mathrm{I} \cdot 0 \mathrm{~mm}$-magnesium chloride, $0.5 \mathrm{~mm}$-dithiothreitol and $10 \mathrm{~mm}-\mathrm{N}$-acetyl cysteine buffer, $\mathrm{pH} 7 \cdot 6$. Following centrifugation at $100000 \mathrm{~g}$ for $40 \mathrm{~min}$, the supernatant fraction was used for quantitation of enzyme activites. FAS was determined by following the rate of NADPH oxidation (Gibson \& Hubbard, I960). G6PD and NADP-ME were measured by following NADP reduction (Lohr \& Walker, I97I; Yeh et al. 1970). GK was assayed by the method of Pilkis (1975). Protein was determined by the microbiuret method of Goa (I953) using bovine serum albumin as standard.

The balance of the liver was used to determine fatty acid synthesis in vivo. It was deposited directly into $5 \mathrm{M}$-potassium hydroxide and heated at $70^{\circ}$ for $3-4 \mathrm{~h}$. After saponification the samples were extracted with three $5 \mathrm{ml}$ portions of light petroleum (b.p. $37 \cdot 8-56 \cdot 1^{\circ}$ ) to remove non-saponifiable material. The samples were then acidified with hydrochloric acid and the fatty acids extracted with three $5 \mathrm{ml}$ portions of light petroleum (b.p. $37.8-$ $56.1^{\circ}$ ). The light petroleum was evaporated and the radioactivity in the extracted fatty acids determined by liquid-scintillation spectrometry.

Absorption coefficients for the dietary fats were determined as described by Clarke et al. (1977a).

\section{RESULTS}

In order to control consumption of diet the mice were trained to eat their daily food allocation in a $3 \mathrm{~h}$ period. The effects of meal-feeding on the variables being studied are shown in Table 3. The rate of lipogenesis measured in vivo was increased twofold. This increase was accompanied by increases in activity of FAS, G6PD and ME of 79, I I 6 and $38 \%$ respectively. The level of GK was unaltered by meal feeding.

Food consumption is shown in Table 4 . It can be seen that there were no differences in consumption among the diets. As the fat content of the diet was increased, the carbohydrate content decreased and therefore so did the carbohydrate consumption by mice. However, for a given fat content, the carbohydrate intake of mice given the maize oil and the tripalmitin diet was the same.

Figs. I-5 illustrate the effects of increasing the amounts of tripalmitin or maize oil in the diet on the rate of lipogenesis in vivo and the activity of FAS, G6PD, ME and GK in liver from meal-fed mice. 
Table I. Composition $(\mathrm{g} / \mathrm{kg})$ of the experimental diets

\begin{tabular}{lr} 
Sucrose & \\
Caesein & $350-600$ \\
Cellulose & 200 \\
AIN mineral mix * & 50 \\
AIN vitamin mix $\dagger$ & 35 \\
Choline chloride & 10 \\
DL-methionine & 02 \\
Maize oil or tripalmitin & 03 \\
\hline
\end{tabular}

- Obtained from ICN Nutritional Biochemicals, Cleveland, Ohio, has the following composition $(\mathrm{g} / \mathrm{kg})$ : $\mathrm{CaHPO}_{4}, 500 ; \mathrm{NaCl}, 74 \cdot 0$; potassium citrate monohydrate, $220 \cdot 0 ; \mathrm{K}_{2} \mathrm{SO}_{4}, 52 \cdot 0 ; \mathrm{MgO}, 24 \cdot 0 ; \mathrm{MnCO}_{3}, 3.5$; ferric citrate, 6.0; $\mathrm{ZnCO}_{2}, 1.6 ; \mathrm{CuCO}_{3}, 0.3 ; \mathrm{KIO}_{3}, 0.01 ; \mathrm{Na}_{2} \mathrm{SeO}_{3} .5 \mathrm{H}_{2} \mathrm{O}, 0.01 ; \mathrm{CrK}\left(\mathrm{SO}_{4}\right)_{2} .12 \mathrm{H}_{2} \mathrm{O}, 0.55$; sucrose, $118 \cdot 0$.

† Obtained from ICN Nutritional Biochemicals, Cleveland, Ohio, has the following composition $(/ \mathrm{kg})$ : thiamine hydrochloride $600 \mathrm{mg}$, riboflavin $600 \mathrm{mg}$, pyridoxine hydrochloride $700 \mathrm{mg}$, nicotinic acid $3 \mathrm{mg}$, D-calcium pantothenate $\mathrm{I} .6 \mathrm{mg}$, folic acid $200 \mathrm{mg}$, D-biotin $20 \mathrm{mg}$, cyanocobalmin I $\mathrm{mg}$, retinyl palmitate $800 \mathrm{mg}$, DL- $\alpha$-tocopheryl acetate $20 \mathrm{~g}$, cholecalciferol $2.5 \mathrm{mg}$, menaquinone $5.0 \mathrm{mg}$, sucrose $972.9 \mathrm{~g}$.

Table 2. Fatty acid composition $(\mathrm{g} / \mathrm{kg})$ of the fats used in the experimental diets

Fatty acid Maize oil Tripalmitin

$\begin{array}{lrc}\text { Palmitic } & 145 & 952 \\ \text { Palmitoleic } & 03 & - \\ \text { Stearic } & 15 & 29 \\ \text { Oleic } & 265 & - \\ \text { Linoleic } & 573 & - \\ \text { Myristic } & - & 19\end{array}$

Table 3. The effect of meal feeding on mouse liver lipogenesis

(Mean values with their standard errors for no. of animals given in parentheses)

\begin{tabular}{|c|c|c|c|c|}
\hline & \multicolumn{2}{|c|}{ Meal-fed (12) } & \multicolumn{2}{|c|}{ ad lib.-fed (8) } \\
\hline & Mean & SE & Mean & SE \\
\hline $\begin{array}{l}\text { In vivo lipogenesis ( } \mu \mathrm{g} \text { atoms }{ }^{8} \mathrm{H} \text { incorporated } \\
\text { into fatty acid } / \mathrm{g} \text { liver per } \mathrm{h} \text { ) }\end{array}$ & $255^{*}$ & 27 & 118 & I4 \\
\hline $\begin{array}{l}\text { Fatty acid synthetase (nmol NADPH oxidized/ } \\
\text { mg protein per min) }\end{array}$ & $17 \cdot 4^{*}$ & $3 \cdot 3$ & $9 \cdot 7$ & $1 \cdot 3$ \\
\hline $\begin{array}{l}\text { Glucose-6-phosphate dehydrogenase } \\
(E C \text { I. I }, \text {. 49) (nmol NADP reduced/mg } \\
\text { protein per min) }\end{array}$ & $67^{* *}$ & 7 & $3 I$ & 3 \\
\hline $\begin{array}{l}\text { Malic enzyme ( } E C \text { I I I I I } 40 \text { ) (nmol NADP } \\
\text { reduced/mg protein per min) }\end{array}$ & $166^{*}$ & 16 & 120 & $7 \cdot 5$ \\
\hline $\begin{array}{l}\text { Glucokinase }(E C 2,7.1 .2)(\text { nmol NADP } \\
\text { reduced } / \mathrm{mg} \text { protein per } \mathrm{min})\end{array}$ & $6 \cdot 7$ & 0.6 & $6 \cdot 9$ & 0.6 \\
\hline
\end{tabular}

Mean values were statistically significantly different from those of ad lib.-fed mice: $\bullet P<0.05,{ }^{* *} P<0.01$.

Fig. I shows the effect of maize oil or tripalmitin on lipogenesis in vivo. Tripalmitin caused inhibition of lipogenesis at $10 \%$ but this inhibition was not increased by additional tripalmitin in the diet. There was significant inhibition of lipogenesis at all levels of maize oil tested. At equal levels of fat in the diet, the inhibition by maize oil was greater than that by tripalmitin.

The effect of corn oil or tripalmitin on the hepatic level activity of FAS is illustrated in Fig. 2. No significant reduction of FAS was observed in tripalmitin-fed mice except at the 
Table 4. Consumption of diets* containing varying amounts of maize oil or tripalmitin $(g /$ mouse per $d)$

(Mean values with their standard errors for eight mice)

\begin{tabular}{ccccc} 
& \multicolumn{2}{c}{ Maize oil } & \multicolumn{2}{c}{ Tripalmitin } \\
\cline { 2 - 3 } Fat (g/kg) & Mean & SE & Mean & SE \\
0 & 2.7 & 0.1 & 2.8 & 0.1 \\
50 & 2.8 & 0.1 & 2.9 & 0.1 \\
100 & 2.7 & 0.1 & 2.7 & 0.1 \\
150 & 2.7 & 0.1 & 2.8 & 0.2 \\
200 & 2.9 & 0.2 & 2.9 & 0.1 \\
250 & 2.8 & 0.1 & 2.7 & 0.1 \\
& For details, see Tables I and 2.
\end{tabular}

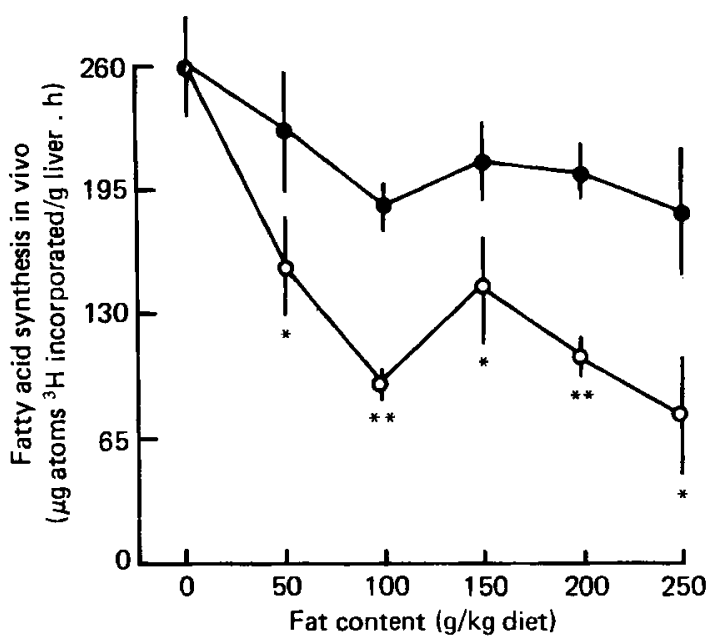

Fig. I. Fatty acid synthesis in vivo ( $\mu \mathrm{g}$ atoms ${ }^{3} \mathrm{H}$ incorporated into fatty acid/g liver per $\mathrm{h}$ ) in relation to maize oil or tripalmitin content of the diet $(\mathrm{g} / \mathrm{kg})$. Fatty acid synthesis was determined from the rate of ${ }^{3} \mathrm{H}$ incorporation from ${ }^{3} \mathrm{H}_{2} \mathrm{O}$ into saponifiable mouse liver lipids as described on p. 572. (O) Maize oil; (O) tripalmitin. Values are means with their standard errors represented by vertical bars for eight to twelve mice. Mean values were significantly different: ${ }^{*} P<00^{\circ} 05,{ }^{* *} P<$ o.or.

highest level fed $(250 \mathrm{~g} / \mathrm{kg})$. Significant reductions of FAS were observed at all levels of maize oil fed. The effect was nearly maximal at $100 \mathrm{~g}$ maize oil $/ \mathrm{kg}$ in the diet. The effect of maize oil was significantly greater than that due to tripalmitin at all levels-fed.

Fig. 3 shows the effect of maize oil or tripalmitin on G6PD. There was significant inhibition at 50 and $150 \mathrm{~g}$ tripalmitin/ $/ \mathrm{kg}$ and a greater inhibition at $250 \mathrm{~g} / \mathrm{kg}$.

The effect of maize oil was much greater and was maximal at $100 \mathrm{~g}$ maize oil $/ \mathrm{kg}$ diet. At all levels, maize oil caused more inhibition than tripalmitin. In fact $50 \mathrm{~g}$ maize oil $/ \mathrm{kg}$ was more effective than $250 \mathrm{~g}$ tripalmitin $/ \mathrm{kg}$.

The result of feeding maize oil or tripalmitin on liver ME is illustrated in Fig. 4. A small but significant inhibition was observed at all levels of tripalmitin fed. At $50 \mathrm{~g}$ maize oil or tripalmitin $/ \mathrm{kg}$ there was no difference in the inhibition observed but at all higher levels maize oil was a more effective inhibitor than tripalmitin.

Liver GK at various levels of dietary tripalmitin or maize oil are seen in Fig. 5. A small inhibition was seen at $100 \mathrm{~g}$ tripalmitin $/ \mathrm{kg}$ which was not increased by higher levels of 


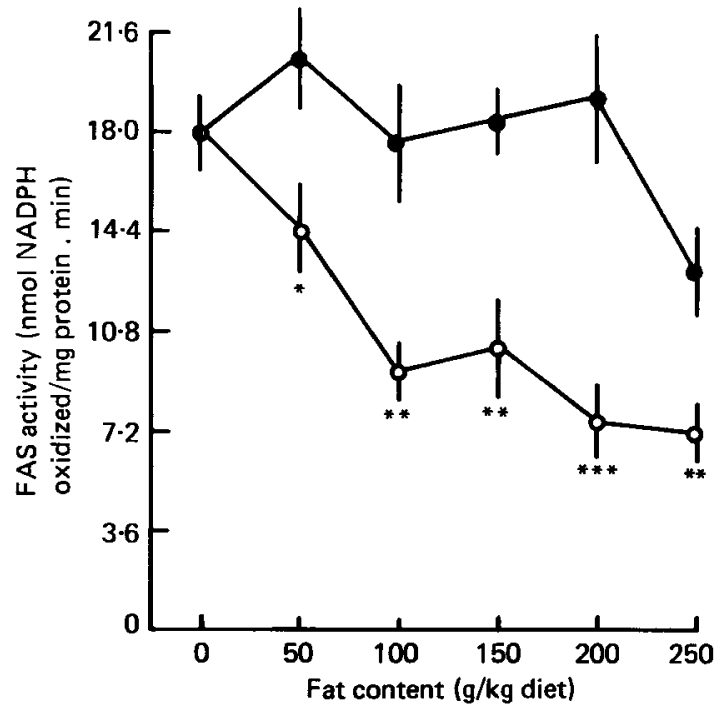

Fig. 2. Activity of fatty acid synthetase (FAS) in liver from mice given different amounts of maize oil or tripalmitin in the diet. FAS was determined on a $100000 \mathrm{~g}$ supernatant fraction of mouse liver homogenate by determining the malonyl-CoA-dependent oxidation of NADPH. (O) Maize oil; (O) tripalmitin. Values are means with their standard errors represented by vertical bars for eight is twelve mice. Mean values were significantly different: $* P<0.05, * * P<0.01, * * * P<$ $0 . \infty \mathrm{I}$.

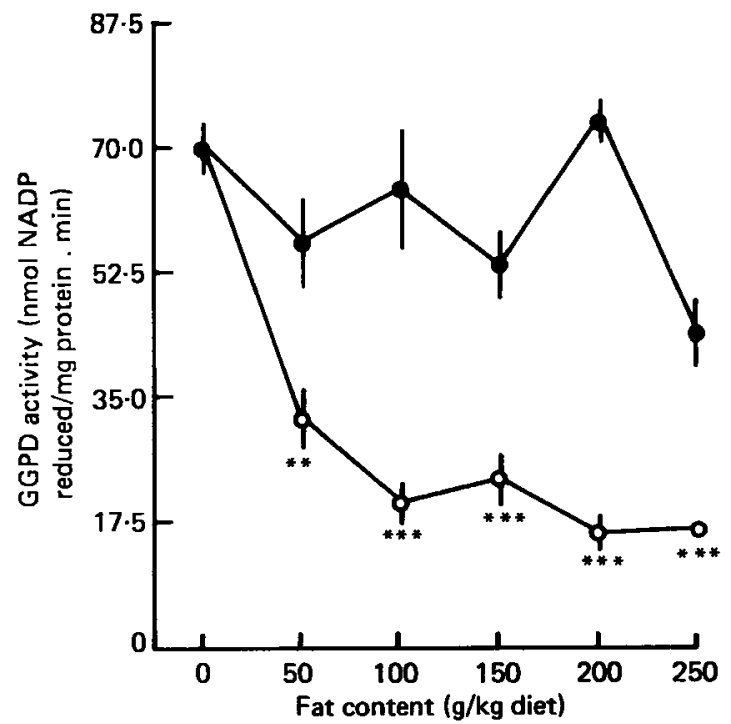

Fig. 3. Activity of glucose-6-phosphate dehydrogenase (EC I I I I .49; G6PD) in liver from mice given different amounts of maize oil or tripalmitin in the diet. G6PD was determined on a $100000 \mathrm{~g}$ supernatant fraction of mouse liver homogenate by determining the glucose-6-phosphate dependent reduction of NADP. (O) Maize oil; (O) tripalmitin. Values are means with their standard errors represented by vertical bars for eight to twelve mice. Mean values were significantly different: $* * P<0.01, * * * P<0.001$. 


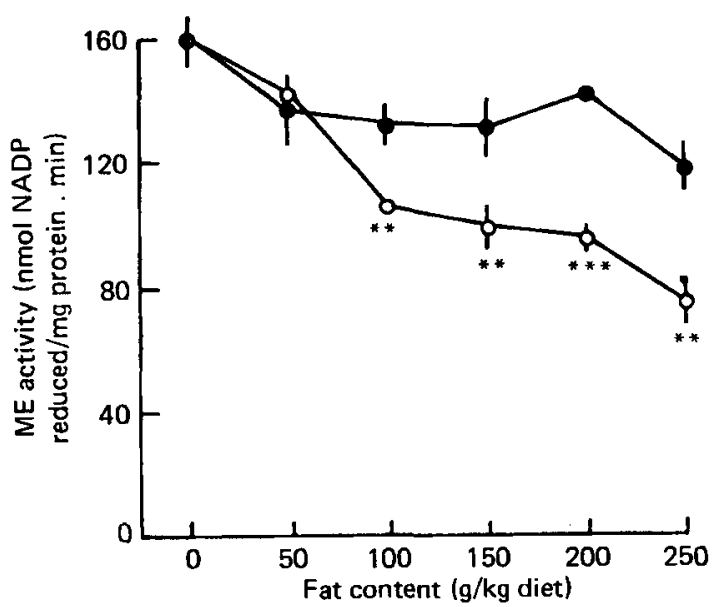

Fig. 4. Activity of malic enzyme ( $E C$ I . 1 . I .40; ME) in liver from mice given different anounts of maize oil or tripalmitin in the diet. ME was determined on a $100000 \mathrm{~g}$ supernatant fraction of mouse liver homogenate by determining the malate dependent reduction of NADP. (O) Maize oil; (-) tripalmitin. Values are means with their standard errors represented by vertical bars for eight to twelve mice. Mean values were significantly different: ${ }^{*} P<0.05,{ }^{* *} P<0.01,{ }^{* * *} P<0.001$.

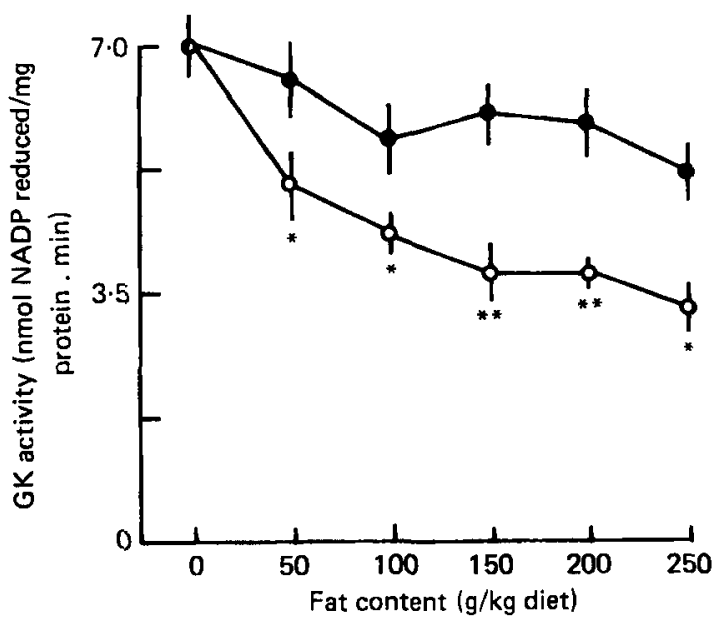

Fig. 5. Activity of glucokinase ( $E C$ 2.7.I .2; GK) in liver from mice given different amounts of maize oil or tripalmitin in the diet. GK was determined on a $100000 \mathrm{~g}$ supernatant fraction of mouse liver homogenate by determining the glucose dependent reduction of NADP. The assay medium contained added glucose-6-phosphate dehydrogenase. Values were corrected for hexokinase activity. (O) Maize oil; (O) tripalmitin. Values are means with their standard errors represented by vertical bars for eight to twelve mice. Mean values were significantly different: ${ }^{*} P<0.05,{ }^{* *} P<0.01$.

tripalmitin. Significant inhibition by maize oil was observed at all levels fed. At all levels of fat in the diet maize oil caused more inhibition than tripalmitin.

\section{DISCUSSION}

The present study demonstrates that mice meal-fed a fat-free diet have an enhanced ability to synthesize fatty acids in the liver compared to mice allowed to consume the same diet ad lib. Secondly, diets containing maize oil when meal-fed to mice were more effective at inhibiting hepatic lipogenesis and at lowering the levels of lipogenic enzymes than diets 
containing tripalmitin. The increased inhibition by maize oil was observed at all levels of dietary fat tested.

Our finding of enhanced liver lipogenesis in meal-fed mice is in contrast to reports from several labs (Jansen et al. I968; Baker \& Huebotter, 1973; Favarger \& Gerlach, I973; Baker et al. 1976; Cornish \& Cawthorne, 1978). The following differences in experimental procedure may account for the observed differences. Cornish \& Cawthorne (1978) using female mice of a different strain fed on a normal mouse diet presumably containing a source of fat. The mice were allowed access to food for $4 \mathrm{~h}$ daily. In the experiments by Baker et al. ( 1976 ) in which comparable period of meal feeding was used ( 2 weeks) the mice were fed twice each day for $2 \mathrm{~h}$ each time. It is possible that these differences account for the differences between this study and those mentioned previously with regard to the effect of mealfeeding.

The results presented on the effect of feeding maize oil and tripalmitin on hepatic lipogenesis support observations from a number of laboratories that fats high in polyunsaturated fatty acids are more inhibitory than saturated fats. Although at each level of fat in the diet examined maize oil was more effective than tripalmitin, tripalmitin was not without a significant effect. Significant inhibition of lipogenesis in vivo as well as depression of the activity of each of the enzymes examined was observed.

These findings are significant since they clearly demonstrate that the differential effect of polyunsaturated fatty acids extend to high levels of fat in the diet.

The finding of greater inhibition of fatty acid synthesis in vivo by maize oil compared to tripalmitin is comparable to that observed by Triscari et al. (1978) who meal-fed maize oil or hydrogenated soya-bean oil. At $100 \mathrm{~g}$ maize oil $/ \mathrm{kg}$ they observed a $70 \%$ inhibition of lipogenesis measured with ${ }^{3} \mathrm{H}_{2} \mathrm{O}$ compared to $60 \%$ inhibition in the present study at the same fat level. However, while we found a $20 \%$ inhibition at $200 \mathrm{~g}$ tripalmitin $/ \mathrm{kg}$, no inhibition by the saturated fat was seen by Triscari et al. (1978). Bartley \& Abraham (I972) measured fatty acid synthesis in vivo from $\left[{ }^{14} \mathrm{C}\right]$ acetate in mouse liver from mice given I $50 \mathrm{~g}$ tripalmitin or safflower $/ \mathrm{kg}$. They found $56 \%$ inhibition by tripalmitin and $93 \%$ inhibition by safflower oil. Sabine et al. (1969) observed $87 \%$ inhibition of fatty acid synthesis by liver slices from mice given $150 \mathrm{~g}$ maize oil $/ \mathrm{kg}$ but no inhibition in those given tripalmitin.

Our finding of greater inhibition of lipogenesis by an unsaturated fat compared to a saturated one is supported by the studies of Clarke et al. $(1976,1977 a, b, c)$ in which low levels of methyl esters of fatty acids were meal-fed to rats resulting in inhibition of lipogenesis in vivo by methyl linoleate but not methyl palmitate.

The activities of lipogenic enzymes do not always reflect rates of fatty acid synthesis of tissue (Tepperman \& Tepperman, I965). However, few studies have been conducted which correlate changes in liver lipogenic enzyme activities due to different dietary fats to rates of hepatic fatty acid synthesis. This is particularly the situation for studies in which several dietary levels of saturated and unsaturated fats are fed. In mice, a small amount of dietary linoleate led to a decline in liver FAS while oleate and palmitate were without effect (Allman \& Gibson, 1965). Muto \& Gibson (1970) showed that in rats on a fat-free diet, oral administration for $3 \mathrm{~d}$ of methyl esters of polyunsaturated fatty acids depressed liver levels of FAS, $\mathrm{ME}, \mathrm{G} 6 \mathrm{PDH}$, acetyl CoA carboxylase $(E C 6.4$. I.2) and citrate cleavage enzyme (EC 4. I.3.8) while administration of methyl palmitate had only a slight inhibitory effect.

Clarke et al. (1977a,b,c) clearly demonstrated the inhibitory effect of methyl linoleate and the lack of an effect of methyl palmitate on lipogenic enzymes in rat liver when these fatty acids are fed at low levels. They also showed that the depression in lipogenic enzyme level is paralleled by an inhibition of lipogenesis in vivo. Since all rats consumed the same amount of carbohydrate in these studies, the effect could not be attributed to decreased 
carbohydrate intake as suggested by Gozukara et al. (1972). In the present study all the mice ate the same amount of diet/d and thus as the fat content increased, the carbohydrate intake decreased. Thus, for a specific fat, the decline in lipogenesis or lipogenic enzymes with increasing amount of dietary fat could be partially due to decreased carbohydrate intake. This appears unlikely, however, as Triscari et al. (1978) have shown that at a given level of fat in the diet, the mice consumed the same amount of carbohydrate and therefore, the enhanced inhibition seen in maize-oil-fed mice is clearly due to the maize oil and not to a difference in carbohydrate intake.

It is possible that some of the difference between maize oil and tripalmitin is due to the difference between the absorption coefficient for these two fats ( 0.985 and 0.545 respectively). Two arguments suggest that the difference is due to the nature of the fat consumed and not to the different amounts absorbed. First, a comparison of the inhibition observed at equivalent levels of absorbed fat (e.g. $120 \mathrm{~g}$ maize oil $/ \mathrm{kg} v .250 \mathrm{~g}$ tripalmitin $/ \mathrm{kg}$ ) shows that for lipogenesis and the enzymes examined maize oil is more inhibitory than tripalmitin. Since mice eating the $250 \mathrm{~g}$ tripalmitin/ $\mathrm{kg}$ eat less carbohydrate than those on either 100 or $\mathrm{I} 50 \mathrm{~g}$ maize oil, the inhibition by maize oil compared to tripalmitin in animals fed the same amount of carbohydrates and equivalent absorbed doses of fat would be even greater.

Secondly, if the lesser effect of tripalmitin is due only to less efficient absorption, then both fats should exhibit the same maximal effect on the factors examined. Determination of the maximum inhibition (\%) caused by the dietary fats used according to the method of Mercer et al. (1978) provided the following values for maize oil and tripalmitin, respectively: fatty acid synthesis in vivo 7I and 30; ME 93 and 19; GK 65 and 55; FAS 94 and 2; G6PD 85 and 32 . From this evaluation it is clear that the maximal inhibition for each variable examined is greater for maize oil than for tripalmitin.

Examination of Figs. $\mathrm{I}-5$ shows a close correlation between the rate of lipogenesis measured in vivo and the activity of several lipogenic enzymes and GK measured in vitro.

In conclusion, we have shown that the differential effect of maize oil compared to tripalmitin is observed in both lipogenesis in vivo and on the activity of FAS, ME, G6PD and GK. Finally, we have demonstrated that this differential effect is seen even at relatively high levels of fat in the diet and is not due to differences in carbohydrate intake or absorbability of the fats used.

This work was supported by the MRC of Canada. The authors wish to thank Dr K. M. W. Keough for performing fatty acid analyses on the fats used.

\section{REFERENCES}

Allman, D. \& Gibson, D. M. (1965). J. Lipid Res. 6, 51.

Baker, N. \& Huebotter, R. J. (1973). J. Lipid Res. 14, 87.

Baker, N., Palmquist, D. L. \& Learn, D. B. (1976). J. Lipid Res. 17, 527.

Bartley, J. C. \& Abraham, S. (1972). Biochim. biophys. Acta 280, 258.

Clarke, S. D., Romsos, D. R. \& Leveille, G. A. (1976). Lipids II, 485.

Clarke, S. D., Romsos, D. R. \& Leveille, G. A. (1977a). J. Nutr. I07, i 70.

Clarke, S. D., Romsos, D. R. \& Leveille, G. A. (1977b). J. Nutr. 107, I 277.

Clarke, S. D., Romsos, D. R. \& Leveille, G. A. (1977 c). J. Nutr. ro7, 1468.

Cornish, S. \& Cawthorne, M. A. (1978). Horm. Metab. Res. 10, 286.

Dupont, J. (1970). Lipids $\mathbf{5}, 908$.

Favarger, P. \& Gerlach, J. (1973). C. r. Séanc. Soc. Biol. 1167, 23.

Gibson, D. M. \& Hubbard, A. W. (1960). Biochem. biophys. Res. Commun. 3, 35 I.

Goa, J. (1953). Scand, J. clin. Lab. Invest. 5, 218.

Gozukara, E. M., Frolich, M. \& Holten, D. (1972). Biochim. biophys. Acta 252, 305.

Hill, R., Linazasoro, J. M. Chevaller, F. \& Chaikoff, I. L. (1958). J. biol. Chem. 233, 305.

Jansen, G. R., Hutchison, C. F. \& Zanetti, M. E. (I966). Biochem. J. 99, 323. 
Jansen, G. R., Zanetti, M. E. \& Hutchison, C. F. (1968). Biochem. J. 106, 345.

Lohr, G. W. \& Walker, H. O. (197I). In Methods of Enzymatic Analysis, vol. 2, p. 636 [H. V. Bergmeyer, editor]. New York: Academic Press.

Mercer, L. P., Flodin, N. W. \& Morgan, P. H. (1978). J. Nutr. ro8, 1244.

Musch, K., Ojakian, M. S. \& Williams, M. A. (1974). Biochem. biophys. Acta 337, 343.

Muto, Y. \& Gibson, D. M. (1970). Biochem. biophys. Res. Commun. 38, 9.

Pilkis, S. J. (1975). Meths. Enzym. 42, 3 I.

Preston, L., Flodin, N. W. \& Morgan, P. H. (1978). J. Nutr. 108, 1244.

Sabine, T. R., McGarth, H. \& Abraham, S. (1969). J. Nutr. 98, 312.

Tepperman, H. \& Tepperman, J. (1965). Am. J. Physiol. 209, 773.

Triscari, J., Hamilton, J. G. \& Sullivan, A. C. (1978). J. Nutr. ro8, 815.

Waterman, R. A., Romsos, D. R., Tsai, A. C., Miller, E. R. \& Leveille, G. A. (1975). Proc. Soc. exp. Biol. Med. 150, 347.

Wiegand, R. D., Rao, G. A. \& Keiser, R. (1973). J. Nutr. 103, I4I4.

Yeh, Y. Y., Leveille, G. A. \& Wiley, J. H. (1970). J. Nutr. roo, 917. 